\title{
PENGARUH FAKTOR - FAKTOR PARTISIPASI \\ TERHADAP TINGKAT PARTISIPASI PETANI ANGGOTA P3A DALAM KEGIATAN PENGELOLAAN SALURAN IRIGASI
}

\author{
Effect Of Participation Factors On Level Of Farmers Participation Of P3A Members \\ In Management Activities Of Irrigation Channel
}

\author{
Rizky Putriani *, A. N. Tenriawaru, A. Amrullah. \\ Program Studi Agribisnis, Departemen Sosial Ekonomi Pertanian, \\ Fakultas Pertanian, Universitas Hasanuddin, Makassar. \\ *Kontak Penulis: Rizkyputriani@gmail.com
}

\begin{abstract}
The agricultural sector has an important and strategic role in national development, including national food supply. The needs of farmers for irrigation water are increasing along with the demands to produce quality crops. The participation of P3A members in managing tertiary irrigation networks will help increase agricultural production. This study aims to: 1) Analize the level of farmer participation in irrigation channel management activities, in Alatengae Village, Bantimurung Subdistrict, Maros Regency, South Sulawesi, and 2) Analize the influence on participation factors with the level of participation of P3A farmers, in Alatengae Village, Bantimurung District, Maros Regency, South Sulawesi. This study used a qualitative-quantitative approach with a research location in Alatengae Village, Bantimurung District, Maros Regency. The results of the study concluded that: 1). Farmer Participation Levels of P3A Members in Irrigation Management Activities at each stage of P3A Mattirioalie (Hulu) and P3A Sitiroang Deceng (Central) in the Medium category, which means that they have not been able to realize full awareness of the importance of irrigation management, while Saromase (Downstream) P3A in the high category. 2). Factors that significantly influence the level of farmer respondents' participation in the P3A group in Alatengae Village are age factors, number of dependents, experience of farming, land area, distance of residence from irrigation channels, distance of paddy fields from irrigation channels. and factors that did not significantly influence the Education Level factor.
\end{abstract}

Keywords: P3A farmers; Participation; Irrigation.

\begin{abstract}
Abstrak
Sektor pertanian mempunyai peranan penting dan strategis dalam pembangunan nasional, diantaranya adalah penyediaan pangan nasional. Kebutuhan petani akan air irigasi kian bertambah seiring dengan tuntutan untuk menghasilkan hasil panen yang berkualitas. Partisipasi anggota P3A dalam mengelola jaringan irigasi tersier akan membantu peningkatan produksi pertanian. Penelitian ini bertujuan untuk: 1) Menganalisis Tingkat partisipasi petani dalam kegiatan pengelolaan saluran irigasi, di Desa Alatengae, Kecamatan Bantimurung, Kabupaten Maros, Sulawesi Selatan, dan 2) Menganalisis pengaruh antara faktor-faktor partisipasi dengan tingkat partisipasi petani P3A, di Desa Alatengae, Kecamatan Bantimurung, Kabupaten Maros, Sulawesi Selatan. Penelitian ini menggunakan pendekatan kualitatif-kuantitatif dengan lokasi penelitian di Desa Alatengae, Kecamatan Bantimurung, Kabupaten Maros. Hasil penelitian menyimpulkan bahwa: 1). Tingkat Partisipasi Petani Anggota P3A dalam Kegiatan Pengelolaan Irigasi di tiap tahap pada P3A Mattirioalie (Hulu) dan P3A sitiroang Deceng (Tengah) masih dalam kategori
\end{abstract}


Sedang. Sedangkan Tingkat Partisipasi pada P3A Saromase (Hilir) berada pada kategori yang tinggi. 2). Adapun faktor-faktor yang mempengaruhi secara signifikan tingkat partisipasi petani responden kelompok P3A di Desa Alatengae yaitu faktor umur, Jumlah tanggungan, Pengalaman Berusahatani, Luas Lahan, Jarak Tempat Tinggal dari Saluran Irigasi, Jarak Sawah dari Saluran Irigasi. dan adapun faktor-faktor yang tidak berpengaruh secara signifikan yaitu faktor Tingkat Pendidikan.

Kata Kunci: Petani P3A; Partisipasi; Irigasi.

Sitasi: Putriani R. *, A. N. Tenriawaru, A. Amrullah, 2018. Pengaruh faktor - faktor partisipasi terhadap tingkat partisipasi petani anggota P3A dalam kegiatan pengelolaan saluran irigasi, JSEP 14(3): 263 - 274.

\section{Pendahuluan}

Pengelolaan sumberdaya air dan irigasi dipandang sebagai salah satu komponen kunci untuk peningkatan ketahanan pangan. Oleh sebab itu, perbaikan irigasi dan pengelolaan air di angkat menjadi salah satu komponen dari special program for food security (SPFS), (Saptana,dkk,2001).

Kebutuhan petani akan air irigasi kian bertambah seiring dengan tuntutan untuk menghasilkan hasil panen yang berkualitas. Arah kebijakan pendayagunaan sumber daya air untuk pemenuhan kebutuhan air irigasi pada lima tahun ke depan, salah satunya adalah peningkatan kinerja dalam pengelolaan saluran irigasi, mengingat kerusakan dan tidak berfungsinya jaringan irigasi disebabkan rendahnya kualitas operasi dan pemeliharaan (Kimpraswil, 2002). Kelompok Petani Pemakai Air sebagai perkumpulan petani pemakai air bertanggung jawab dalam pembangunan dan peningkatan jaringan tersier dan dapat berperan serta dalam pengelolaan jaringan irigasi keseluruhan, sedangkan pemerintah bertanggung jawab dalam pembangunan jaringan irigasi primer dan sekunder. Langkah ini diharapkan banyak pihak menjadi embrio pemberdayaan petani di dalam pengembangan daerah irigasi dan reklamasi rawa (Kolopaking dan Nawireja, 2001).

Kebijakan pemerintah mengenai pengelolaan sistem irigasi telah ditetapkan dalam 2 (dua) landasan hukum yakni undang-undang No. 7 tahun 2004 tentang Sumber Daya Air dan Peraturan Pemerintah No. 20 tahun 2006 tentang Irigasi, mengamanatkan bahwa tanggung jawab pengelolaan jaringan irigasi tersier sampai ke tingkat usaha tani dan jaringan irigasi desa menjadi hak dan tanggung jawab petani yang terhimpun dalam wadah Perkumpulan Petani Pemakai Air (P3A) sesuai dengan kemampuannya.

Partisipasi anggota P3A dalam mengelola jaringan irigasi tersier akan membantu peningkatan produksi pertanian, yang salah satunya adalah Kabupaten Maros sebagai daerah lumbung padi di Sulawesi Selatan, tentunya sangat membutuhkan partisipasi anggota P3A sebagai objek sekaligus subjek pembangunan. Setiap tahun, Kabupaten Maros menjadi salah satu penyangga beras untuk wilayah di sekitarnya, termasuk Makassar. Luas daerah irigasi Kabupaten 
Maros yang telah dibangun mencapai $20.222 \mathrm{Ha}$, yang tersebar di lima puluh lima daerah irigasi yang berada di Kabupaten Maros, dengan luas area terluas di daerah irigasi Bantimurung yaitu 6.513 Ha (BPS,2013)

Daerah aliran sungai Bantimurung yang merupakan salah satu daerah pengembangan irigasi yang berada di kabupaten Maros memiliki saluran irigasi yang terdiri atas saluran terminal (utama), sekunder, dan tersier. Sumber airnya berasal dari alam, yaitu dari aliran sungai bantimurung. Sebagian besar daerah ini tidak dialiri selama musim kemarau, begitu juga pada musim hujan karena persediaan air tidak mencukupi, dan tidak stabilnya aliran air sungai. Sehingga demi berkelanjutan saluran irigasi dan kinerjanya sangat penting pengalaman dari kegiatan-kegiatan ditentukan oleh keterlibatan dan partisipasi dari penerima manfaat. Berdasarkan uraian diatas, peneliti terdorong untuk melakukan penelitian dengan judul "Pengaruh Faktor-Faktor Partisipasi Terhadap Tingkat Partisipasi Petani Anggota P3A Dalam Kegiatan Pengelolaan Saluran Irigasi Bantimurung, Desa Alatengae, Kecamatan Bantimurung, Kabupaten Maros, Sulawesi Selatan)”.

\section{Metode Penelitian}

Penelitian ini dilaksanakan di Desa Alatengae, Kecamatan Bantimurung, Kabupaten Maros, Provinsi Sulawesi Selatan. Pemilihan lokasi dilakukan dengan sengaja (purposive sampling) berdasarkan rekomendasi PU Pengairan. P3A yang ditetapkan pada Desa Alatengae adalah P3A Mattirioalae (Hulu), P3A Saromase (Tengah), P3A Sittiroang deceng (Hilir) dengan dasar pertimbangan bahwa daerah ini merupakan daerah aliran irigasi Bantimurung dan mayoritas penduduknya bekerja di sektor pertanian.. Adapun sampel dalam penelitian ini sebanyak 33 orang atau $10 \%$ dari 333 jumlah populasi yang ada. Data yang digunakan dalam penelitian ini adalah data primer dan data sekunder. Teknik pengumpulan data dilakukan dengan wawancara serta menggunakan instrumen penelitian berupa kuisioner yang diberikan kepada sampel penelitian petani anggota P3A.

Untuk tujuan pertama fokus ke analisis kualitatif. Tingkat Partisipasi Anggota P3A dalam pengelolaan irigasi tersier dalam penelitian ini adalah keikutsertaan anggota P3A dalam seluruh tahapan kegiatan program. yaitu tahapan dalam tahap Perencanaan, pelaksanaan, evaluasi, serta pemanfaatan hasil. Tingkat partisipasi anggota P3A diukur dengan memberi skor pada item pertanyaan yang menyatakan tingkat partisipasi petani dalam pengelolaan saluran irigasi. Penskoran digunakan dengan menggunakan skala Likert. Menurut Sutrisno Hadi (1991), skala Likert merupakan skala yang berisi lima tingkat jawaban mengenai kesetujuan responden terhadap statemen atau pernyataan yang dikemukakan mendahului opsi jawaban yang disediakan dengan lima opsi jawaban yaitu skor untuk 5 tingkat partisipasi sangat tinggi. Skor 4 untuk tingkat partisipasi tinggi. Skor 3 untuk tingkat partisipasi sedang. Skor 2 untuk tingkat partisipasi rendah. Skor 1 untuk tingkat partisipasi sangat rendah. Selanjutnya data dengan skala ordinal yang diperoleh akan ditransformasi menjadi data skala interval dengan bantuan MSI (Method Successive Interval), Hasil pengukuran dari variabel penelitian akan dklasifikasikan dalam tiga klasifikasi Tinggi, sedang, rendah. untuk memperoleh standar tinggi rendahnya 
tingkat partisipasi petani responden pada kegiatan pengelolaan saluran irigasi maka digunakan rumus Sturges (Dajan, 1986) sebagai berikut:

$$
\begin{aligned}
& \mathrm{z}=(\mathrm{x}-\mathrm{y}) / \mathrm{k} \\
& \text { Dimana: } \\
& Z=\text { Interval Kelas } \\
& \mathrm{X}=\text { Nilai Tertinggi } \\
& \mathrm{Y}=\text { Nilai Terendah } \\
& \mathrm{K}=\text { Banyaknya kelas atau kategori }
\end{aligned}
$$

Selanjutnya tujuan kedua digunakan analisis kuantitatif dengan menggunakan Analisis Regresi Linier Berganda. Analisis ini digunakan untuk mengetahui besarnya pengaruh variabel-variabel bebas $\left(x_{1}\right)$ Umur, $\left(x_{2}\right.$ ) Tingkat Pendidikan, $\left(x_{3}\right)$ jumlah tanggungan keluarga, $\left(x_{4}\right)$ Pengalaman Ber usahatani, $\left(x_{5}\right)$ luas lahan usahatani, $\left(x_{6}\right)$ jarak dari tempat tinggal ke tempat kegiatan, $\left(x_{7}\right)$ jarak sawah dari tempat kegiatan Terhadap tingkat partisipasi sebagai variabel tak bebas (Y).

$$
Y=B_{0}+B_{1} x_{1}+B_{2} x_{2}+B_{3} x_{3}+B_{4} x_{4}+B_{5} x_{5}+B_{6} x_{6}+B_{7} x_{7}
$$

\section{Dimana :}

$$
\begin{aligned}
& \mathrm{Y}=\text { Tingkat Partisipasi (Skor) } \mathrm{X} \\
& B_{0}=\text { Titik potong (intercept) } \\
& B_{i}=\text { Parameter Regresi, untuk } \mathrm{i}=1,2,3,4,5,6,7 \\
& x_{1}=\text { Umur Petani/ Responden (Tahun) } \\
& x_{2}=\text { Tingkat Pendidikan Petani/ Responden (Tahun) } \\
& x_{3}=\text { Jumlah Tanggungan Keluarga (Jiwa) } \\
& x_{4}=\text { Pengalaman Berusahatani Petani/Responden (Tahun) } \\
& x_{5}=\text { Luas Lahan Usahatani (Ha) } \\
& x_{6}=\text { Jarak dari tempat tinggal dari saluran irigasi (m) } \\
& x_{7}=\text { Jarak Sawah dari saluran irigasi (m) } \\
& \mathrm{E}=\text { Peubah pengganggu. }
\end{aligned}
$$

\section{Hasil dan Pembahasan}

\subsection{Tingkat Partisipasi Anggota P3A}

Dalam penelitian ini tingkat partisipasi dari ke 4 tahap kegiatan Pengelolaan Saluran Irigasi P3A di Desa Alatengae yaitu : P3A Mattirioalie, Sitiroang Deceng dan Saromase yang dapat dilihat pada tabel 1 berikut :

Tabel 1.

Tingkat Partisipasi Petani Anggota P3A di Kabupaten Maros, 2018

\begin{tabular}{llll}
\hline Aktivitas & Kisaran Skor & Skor & Tingkat Partisipasi \\
\hline Perencanaan - Pemanfaatan Hasil & $20-100$ & 65.33 & Sedang \\
Perencanaan - Pemanfaatan Hasil & $20-100$ & 68.04 & Sedang \\
Perencanaan - Pemanfaatan Hasil & $20-100$ & 77.72 & Tinggi \\
\hline
\end{tabular}


Tabel 1 menunjukkan tingkat partisipasi anggota P3A di Desa Alatengae dalam pengelolaan saluran irigasi masih berada dalam kategori sedang sampai tinggi. Hal ini berarti bahwa petani anggota P3A Mattirioalie belum menyadari secara penuh akan perannya untuk menyumbangkan tenaga, ide, atau pikiran. Petani anggota P3A Mattirioalie ini hanya ingin menikmati hasilnya tanpa ingin ikut lebih untuk berpartisipasi tinggi pada tiap tahap pegelolaan irigasi. Hal ini sesuai dengan hasil wawancara bersama bapak Mustari selaku ketua P3A di Mattirioalie yang menyatakan bahwa anggota P3A nya masih banyak yang ogah-ogahan untuk turun langsung berpartisipasi pada semua kegiatan pengelolaan karena banyak anggotanya merasa tidak terlalu mempengaruhi hasil produksinya karena ketersediaan dan alokasi air yang selalu ada. Jadi keinginan untuk berpartisipasi penuh belum terlalu tinggi di P3A Mattirioalie ini.

Sementara tingkat partisipasi di P3A Sitiroang Deceng rata-rata menunjukkan tingkat partisipasi petani masih berada dalam kategori sedang yaitu sebesar $(67,08)$ hal ini berarti bahwa petani anggota P3A Sitiroang Deceng sama dengan P3A Mattirioalie yang belum menyadari secara penuh akan perannya untuk menyumbangkan tenaga, ide, atau pikiran. Petani anggota P3A Sitiroang Deceng ini rata-rata hanya ingin menikmati hasilnya tanpa ingin ikut andil untuk berpartisipasi tinggi pada tiap tahap pegelolaan irigasi. Hal ini sesuai dengan hasil wawancara bersama bapak Muh nurdin selaku ketua P3A di Sitiroang Deceng yang menyatakan bahwa anggota P3A nya sebenarnya ingin berpartisipasi penuh namun pengalaman selama ini menunjukkan bahwa kurangnya interaksi yang dilakukan dengan petani lainnya sehingga dampak dari kurangnya interaksi tersebut menyebabkan petani tidak menyadari akan tugas yang harus di emban dan tanggung jawab penuh dalam anggota P3A pada kegiatan pengelolaan irigasi sehingga partisipasi yang diperoleh masih terbilang sedang.

Kemudian tingkat partisipasi di P3A Saromase rata-rata menunjukkan tingkat partisipasi petani berada dalam kategori Tinggi yaitu sebesar $(77,90)$ dimana anggota P3A Saromase telah menyadari secara penuh akan perannya untuk menyumbangkan tenaga, ide, atau pikiran serta menerima dengan baik tugas dan bertanggung jawab penuh dalam mengelola saluran irigasi yang berdampak pada kegiatan usahataninya. sehingga tingkat partisipasi yang mereka peroleh tinggi. Hal ini sesuai dengan hasil wawancara bersama bapak $\mathrm{Hj}$. Jamaluddin selaku ketua P3A di Saromase yang menyatakan bahwa sebelum kegiatan pengelolaan ini bisa dilaksanakan dengan baik sesuai prosedur yang direncanakan partisipasi petani anggota P3A Saromase bisa dikatakan belum terlalu aktif dikarenakan karakteristik petani anggota P3A yang tidak peduli akan tugas dan tanggung jawab yang diberikan serta kurangnya interaksi sesama anggota lainnya sehingga mereka kurang memahami akan manfaat yang mereka rasakan pada pengelolaan irigasi, sehingga timbul berbagai masalah dari petani yang merasakan bahwa alokasi/distribusi air yang begitu sulit tersampaikan pada kegiatan usahataninya. Namun seiring berjalannya waktu kami memberikan dorongan yang kuat kepada anggota P3A saromase akan pentingnya kesadaran untuk turut berpartisipasi penuh dalam kegiatan pengelolaan irigasi ini karena dari partisipasi yang aktif ini akan berimbas kepada manfaat yang mereka rasakan terutama masalah hasil produksi 
mereka yang meningkat, terbukti bahwa dari hasil tingkat partisipasi yang diperoleh petani anggota P3A saromase yang tinggi menunjukkan bahwa mereka memang serius dalam menjalankan tugas dan tanggung jawab yang diberikan. Serta kami juga memberikan dorongan untuk terus melakukan interaksi sesama petani lainnya sehingga membuktikan bahwa dari dorongan interaksi tersebut membuat tingkat partisipasi di P3A Saromase ini menjadi tinggi.

\subsection{Pengaruh Faktor-faktor Partisipasi Terhadap Tingkat Partisipasi}

Dalam penelitian ini yang diduga mempengaruhi tingkat partisipasi petani (Y) di irigasi Bantimurung yaitu : Umur, Tingkat pendidikan, Jumlah Tanggungan, Luas Lahan, Jarak tempat tinggal dari saluran irigasi, Letak sawah dari saluran irigasi. adapun hasil pendugaan variabel faktor-faktor yang mempengaruhi produksi padi petani kelompok P3A dapat dilihat pada tabel 2.

Tabel 2.

Pengaruh Faktor Partisipasi Terhadap Tingkat Partisipasi Petani P3A di Kabupaten Maros, 2018

\begin{tabular}{llll}
\hline Variabel & $\mathrm{B}$ & t hitung & Signifikansi \\
\hline (Constant) & 76.653 & 6.268 & 0.000 \\
Umur $\left(\boldsymbol{x}_{\mathbf{1}}\right)$ & -0.892 & -2.730 & 0.011 \\
Tingkat Pendidikan $\left(\boldsymbol{x}_{\mathbf{1}}\right)$ & 2.118 & 1.274 & 0.214 \\
Jumlah Tanggungan Keuarga $\left(\boldsymbol{x}_{\mathbf{2}}\right)$ & 1.855 & 1.530 & 0.013 \\
Pengalaman Berusahatani $\left(\boldsymbol{x}_{\mathbf{3}}\right)$ & 1.322 & 3.248 & 0.003 \\
Luas Lahan $\left(\boldsymbol{x}_{\mathbf{4}}\right)$ & 3.691 & 2.487 & 0.020 \\
Jarak Tempat Tinggal irigasi $\left(\boldsymbol{x}_{\mathbf{5}}\right)$ & -0.007 & -2.942 & 0.007 \\
Letak Sawah $\left(\boldsymbol{x}_{\mathbf{6}}\right)$ & 0.019 & 3.723 & 0.001 \\
\hline $\mathrm{R}^{2}$ & 0.635 & \\
$\mathrm{~F}_{\text {hitung }}$ & 6.202 & \\
$\mathrm{~F}_{\text {tabel }}$ & $2.49(\alpha=0.05)$ & \\
$\mathrm{T}_{\text {tabel }}$ & $1,693(\alpha=0.05)$ & \\
Signifikansi F Hitung & 0.000 & \\
\hline
\end{tabular}

\section{Uji Determinasi $\left(\mathbf{R}^{2}\right)$}

Niilai koefisien determinasi $\left(\mathrm{R}^{2}\right)$, kelompok P3A di Desa Alatengae sebesar 0,635, maka dapat dikatakan bahwa kemampuan variabel bebas dalam memberikan informasi terhadap variabel terikat tergolong baik. Sehingga dapat disimpulkan bahwa variabel bebas seperti umur, tingkat pendidikan, jumlah tan ggungan, pengalaman berusahatani, luas lahan, jarak tempat tinggal dari saluran irigasi, letak sawah dari saluran irigasi mempunyai pengaruh sebesar 63,5\% terhadap tingkat partisipasi, sedangkan sisanya dijelaskan oleh faktor lain yang tidak dimasukkan dalam model karena tidak dapat di ukur secara kuantitatif.

\section{Analisis Uji F}

Uji F merupakan uji yang bertujuan untuk mengetahui keberartian nilai $\mathrm{R}^{2}$. Dari uji F, nilai $F_{\text {hitung }}$ kelompok P3A di Desa Alatengae sebesar 6.202 dan nilai signifikansinya 0,000. Nilai $F_{\text {tabel }}$ dengan tingkat kepercayaan $95 \%(\alpha=0,05)$ untuk $d f$ 
$\mathrm{N} 1=7$ dan df N2 = 25 sebesar 2,49. Dari hasil pengujian, dapat diambil kesimpulan bahwa nilai $F_{\text {hitung }}>F_{\text {tabel }}$ maka Ho ditolak, artinya seluruh variabel bebas yang meliputi umur, tingkat pendidikan, jumlah tanggungan, pengalaman berusahatani, luas lahan, jarak tempat tinggal dari saluran irigasi, letak sawah dari saluran irigasi berpengaruh terhadap variabel terikat yaitu tingkat partisipasi.

\section{Analisis Uji t}

Uji $\mathrm{t}$ bertujuan untuk mengetahui pengaruh variabel bebas secara parsial terhadap variabel terikat. Uji $\mathrm{t}$ pada ketiga kelompok P3A dilakukan dengan membandingkan nilai $t_{\text {hitung }}$ dengan nilai $t_{\text {tabel }}$, dengan tingkat kepercayaan $95 \%$ ( $\alpha=$ 0.05) dan degree of freedom (df) dengan rumus $n-1$, diperoleh nilai tabel yaitu 1,693. adapun hasil analisis regresi variabel bebas yang berpengaruh terhadap tingkat partisipasi sebagai berikut.

\section{a. Umur}

Nilai koefisien regresi variabel umur pada tingkat partisipasi mempunyai tanda negatif yang besarnya adalah $-0.892 \mathrm{Hal}$ ini berarti bahwa setiap peningkatan 1 satuan umur diduga akan menurunkan tingkat partisipasi sebesar 0,892. Kontribusi umur terhadap tingkat partisipasi berpengaruh secara signifikan. Hal ini dapat dilihat pada nilai signifikansi umur lebih kecil dari taraf nyata 0,05 yaitu sebesar 0,011 maka Ho ditolak.

Berdasarkan hasil pengamatan di lapangan, dimana secara rata-rata usia para petani kelompok P3A di Desa Alatengae ini masih tergolong produktif yaitu $\leq 55$, dengan perolehan tingkat partisipasi yang beragam. karena salah satu kecenderungan petani untuk mau berpartisipasi pada suatu kegiatan disebabkan karena faktor fisik berupa umur, yang artinya umur petani kelompok P3A di Desa Alatengae berpengaruh terhadap tingkat partisipasi dimana petani mampu kerjasama secara dinamis dan memberikan peluang untuk digerakkan dalam melakukan pengembangan potensi diri mereka serta mempengaruhi kemampuan fisik dan cara berpikir. Hal ini sejalan dengan pendapat Mantra (2004) yang menyatakan bahwa usia produktif tersebut merupakan usia ideal untuk bekerja dengan baik dan masih kuat untuk melakukan kegiatan-kegiatan di dalam usahatani dan di luar usahatani serta memiliki kemampuan yang besar dalam menyerap informasi dan teknologi yang inovatif di bidang pertanian.

\section{b. Tingkat Pendidikan}

Nilai koefisien regresi variabel tingkat pendidikan pada tingkat partisipasi mempunyai tanda positif yang besarnya adalah 2.118. Hal ini berarti bahwa setiap peningkat satu tingkat pendidikan diduga akan meningkatkan tingkat partisipasi sebesar 2,118. Kontribusi tingkat pendidikan terhadap tingkat partisipasi tidak berpengaruh secara signifikan. Hal ini dapat dilihat pada nilai signifikansi tingkat pendidikan lebih besar dari taraf nyata 0,05, yaitu sebesar 0,214 maka Ho diterima.

Berdasarkan hasil pengamatan dilapangan bahwa tingkat pendidikan pada petani responden di kelompok P3A di Desa Alatengae ini secara rata-rata berada 
pada kategori tingkat pendidikan yang sedang (SMP) dengan tingkat partisipasi yang beragam dalam pengelolaan irigasi. namun dengan tingkat pendidikan yang sedang petani P3A tetap ingin berpartisipasi dalam pengelolaan saluran irigasi. hal tersebut dikarenakan petani selama ini telah memperoleh informasi dan pengetahuan yang lebih beragam melalui pengalaman-pengalamanya dalam berusahatani. Hal ini sesuai dengan pendapat Notoadmojo (2010), yang menyatakan bahwa pendidikan akan mempengaruhi kognitif seseorang dalam peningkatan pengetahuan. Hasil penelitian ini tidak menujunjukkan pengaruh yang nyata karena pengetahuan tidak hanya dibentuk satu faktor saja yaitu pendidikan tetapi ada faktor lain yang juga mempengaruhi pengetahuan seseorang misalnya pengalaman, informasi, kepribadian dan lainnya.

\section{c. Jumlah Tanggungan Keluarga}

Nilai koefisien regresi variabel jumlah tanggungan keluarga pada tingkat partisipasi mempunyai tanda Positif yang besarnya adalah 1,855. Hal ini berarti bahwa setiap peningkatan satu satuan jumlah tanggungan keluarga diduga akan meningkatkan tingkat partisipasi sebesar 1,855. Kontribusi jumlah tanggungan keluarga terhadap tingkat partisipasi berpengaruh secara signifikan. Hal ini dapat dilihat pada nilai signifikansi jumlah tanggungan keluarga lebih kecil dari taraf nyata 0,05 yaitu sebesar 0.013 , maka Ho ditolak.

Hal tersebut sesuai dengan hasil pengamatan dilapangan yang menunjukkan bahwa petani responden kelompok P3A di Desa Alatengae secara rata-rata berada pada jumlah tanggungan dalam kategori banyak yaitu $>4$ orang dengan tingkat partisipasi yang beragam dalam pengelolaan irigasi. hal ini dikarenakan beberapa petani di Desa Alatengae menganggap dengan jumlah tanggungan yang banyak membuat petani terdorong untuk melakukan banyak aktivitas pada suatu kegiatan serta terdorong untuk menerima/ merespon inovasi baru agar dapat menambah pendapatan keluarganya. hal ini sesuai dengan pendapatn Hasyim (2003) yang menyatakan bahwa banyaknya jumlah tanggungan keluarga akan mendorong seseorang untuk melakukan banyak aktivitas terutama dalam mencari dan menambah pendapatan keluarganya. Semakin banyak anggota keluarga akan semakin besar pula beban hidup yang akan ditanggung atau harus dipenuhi.

\section{d. Pengalaman Berusahtani}

Nilai koefisien regresi variabel pengalaman berusahtani pada tingkat partisipasi mempunyai tanda positif yang besarnya adalah 1,332. Hal ini berarti bahwa setiap kenaikan satu satuan pengalaman berusahatani diduga akan menaikkan tingkat partisipasi sebesar 1,332. Kontribusi pengalaman berusahtani terhadap tingkat partisipasi berpengaruh secara signifikan. Hal ini dapat dilihat pada nilai signifikansi pengalaman berusahtani lebih kecil dari taraf nyata 0,05 yaitu sebesar 0.003, maka Ho ditolak.

Hal tersebut sesuai dengan hasil pengamatan dilapangan yang menunjukkan bahwa petani responden kelompok P3A di Desa Alatengae secara rata-rata sudah tergolong lama dalam berusahatani atau berpengalaman dalam usahatani yaitu di atas 20 tahun dengan lamanya pengalaman para petani kelompok P3A ini 
menunjukkan tingkat partisipasi yang beragam dalam pengelolaan irigasi. yang artinya bahwa semakin berpengalamanya petani dalam berusahatani dapat mendorong petani untuk berpartisipasi lebih tinggi pada suatu kegiatan yaitu pengelolaan saluran irigasi karena tingkat pengalaman berusahatani yang dimiliki petani secara tidak langsung akan mempengaruhi pola pikir petani. hal ini sesuai dengan pendapat Sumaryanto (2009) yang menyatakan bahwa pengalaman juga dapat memberikan pengaruh terhadap minat petani dalam mengelola lahan pertaniannya karena dengan banyaknya pengalaman yang mereka miliki maka akan ada banyak cara yang dapat mereka lakukan untuk meningkatkan produksi pertaniannya.Pengalaman berusahatani merupakan suatu produk dari proses belajar yang dapat menghasilkan kemampuan untuk bekerjasama melalui interaksi sosial yang menjadi kekuatan dinamik untuk beradaptasi. Pola adaptasi membutuhkan dukungan partisipasi petani dalam ikatan kelembagaan, sehingga pengalaman berusahatani berpengaruh dengan tingkat partisipasi petani melalui suatu kelembagaan P3A.

\section{e. Luas Lahan UT}

Nilai koefisien regresi variabel luas lahan UT pada tingkat partisipasi mempunyai tanda positif yang besarnya adalah 3,691. Hal ini berarti bahwa setiap peningkatan 1 satuan luas lahan UT diduga akan menaikkan tingkat partisipasi sebesar 3,691. Kontribusi luas lahan UT terhadap tingkat partisipasi berpengaruh secara signifikan. Hal ini dapat dilihat pada nilai signifikansi luas lahan UT lebih kecil dari taraf nyata 0,05 yaitu sebesar 0,020, maka Ho ditolak.

Hal tersebut sesuai dengan hasil pengamatan dilapangan yang menunjukkan bahwa petani responden kelompok P3A di Desa Alatengae secara rata-rata memiliki luas lahan yang luas yaitu $>1$ Ha dengan luas lahan yang dimiliki petani P3A ini menunjukkan tingkat partisipasi yang beragam dalam pengelolaan irigasi. yang berarti bahwa luas lahan sudah cukup mendorong beberapa petani untuk ikut berpartisipasi lebih tinggi dalam pengelolaan saluran irigasi ini. Hal ini sesuai dengan pendapat Indrawati (2003) yang menyatakan bahwa partisipasi petani dalam suatu kegiatan dipengaruhi oleh kondisi fisik lapangan (luas lahan). Dari hasil ini, dapat ditarik makna bahwa semakin luas lahan garapan yang dikelola, maka besar pula kecenderungan petani untuk berpartisipasi dalam penerapan petunjukpetunjuk yang dianjurkan dalam suatu kegiatan pada usahatani.

\section{f. Jarak Tempat Tinggal dari Saluran Irigasi}

Nilai koefisien regresi variabel jarak tempat tinggal dari saluran irigasi pada tingkat partisipasi mempunyai tanda negatif yang besarnya adalah $-0,007$. Hal ini berarti bahwa setiap peningkatan 1 satuan jarak tempat tinggal dari saluran irigasi diduga akan menurunkan tingkat partisipasi sebesar 0,007. Kontribusi jarak tempat tinggal dari saluran irigasi terhadap tingkat partisipasi berpengaruh secara signifikan. Hal ini dapat dilihat pada nilai signifikansi jarak tempat tinggal dari saluran irigasi lebih kecil dari taraf nyata 0,05 yaitu sebesar 0,007, maka Ho ditolak.

Hal tersebut sesuai dengan hasil pengamatan dilapangan yang menunjukkan bahwa petani responden kelompok P3A di Desa Alatengae rata-rata memiliki jarak 
tempat tinggal yang dekat dengan saluran irigasi yaitu $\leq 1500$ dengan jarak tempat tinggal yang tergolong dekat ini menunjukkan tingkat partisipasi yang beragam dalam pengelolaan irigasi. dimana salah satu kecenderungan seseorang untuk mau berpartisipasi pada suatu kegiatan disebabkan karena faktor fisik berupa jarak. untuk melihat tingkat partisipasi petani jarak yang dimaksud adalah jarak tempat tinggal dari saluran irigasi. petani yang memiliki jarak tempat tinggal yang jauh akan memerlukan sarana serta akomodasi yang lebih untuk sampai ketempat tujuan, dan juga petani akan menurunkan tingkat efisien waktu untuk sampai ketujuan oleh sebab itu partisipasi yang di dapatkan beragam. Hal ini sesuai dengan pendapat Yuswanto dalam Yuni Antika (2017) yang menyatakan bahwa jarak tempat tinggal dari saluran irigasi merupakan faktor penting dalam berpartisipasi dimana petani responden harus menempuh jarak menuju saluran irigasi. Semakin jauh jaraknya maka waktu yang terbuang semakin banyak, tingkat efisiensi waktu menurun, akibatnya partisipasi akan semakin berkurang.

\section{g. Jarak Sawah dari Saluran Irigasi}

Nilai koefisien regresi variabel letak sawah dari saluran irigasi pada tingkat partisipasi mempunyai tanda positif yang besarnya adalah 0,019. Hal ini berarti bahwa setiap kenaikan satu satuan letak sawah dari saluran irigasi diduga akan menaikkan tingkat partisipasi sebesar 0,019. Kontribusi letaksawah dari saluran irigasi terhadap tingkat partisipasi berpengaruh secara signifikan. Hal ini dapat dilihat pada nilai signifikansi letak sawah dari saluran irigasi lebih kecil dari taraf nyata 0,05 yaitu sebesar 0,001 , maka Ho ditolak.

Hal tersebut sesuai dengan hasil pengamatan dilapangan yang menunjukkan bahwa petani responden kelompok P3A di Desa Alatengae rata-rata memiliki letak sawah yang jauh dengan saluran irigasi yaitu > 500 dengan rata-rata letak sawah yang tergolong jauh ini menunjukkan tingkat partisipasi yang beragam dalam pengelolaan irigasi. dimana salah satu kecenderungan seseorang untuk mau berpartisipasi pada suatu kegiatan disebabkan karena faktor fisik letak sawah. untuk melihat tingkat partisipasi petani letak sawah yang dimaksud adalah letak sawah dari saluran irigasi. petani yang memiliki letak sawah yang jauh akan memerlukan sarana serta akomodasi yang lebih untuk sampai ketempat tujuan, dan petani akan menurunkan tingkat efisien waktu untuk sampai ketujuan, serta hal yang paling penting dimana apabila letak sawah jauh dari saluran irigasi maka penyampaian air atau distribusi air kesawah petani menjadi terlambat oleh sebab itu partisipasi yang di dapatkan beragam. hal tersebut sesuai dengan pendapat Rais (2010) yang menyatakan bahwa lahan sawah yang dekat dengan bendung dan pintu air saluran irigasi akan lebih cepat menerima air disbanding dengan lahan sawah yang jauh dari pintu air saluran irigasi. karna tidak mengalami proses evaporasi yang panjang.

\section{Uji Asumsi Klasik}

\section{Uji Normalitas}

Uji normalitas bertujuan untuk menguji apakah data berdistribusi normal atau tidak. Salah satu cara untuk melihat normalitas data pada model regresi dapat menggunakan uji One Sample Kolmogorov Smirnov. Pada penelitian ini, didapat hasil 
Asymtotic Significance pada kelompok P3A di desa alatengae sebesar 0,135 yang lebih besar dari pada 0,05. Berdasarkan hasil tersebut maka dapat disimpulkan bahwa data berdistribusi normal

\section{Uji Heteroskedasitas}

Uji heteroskedastisitas bertujuan untuk menguji apakah pada model regresi terjadi ketidaksamaan varian dari residual satu pengamatan ke pengamatan yang lain. Untuk menguji heteroskedastisitas dari model regresi digunakan uji Glejser. Uji Glejser dilakukan dengan meregresikan variabel-variabel bebas terhadap nilai absolute residualnya. Apabila menghasilkan signifikansi $>0,05$. Maka variabel pada model regresi yang digunakan tidak terjadi gejala heteroskedasitas. Pada peneltian ini didapatkan nilai signifikansi di kelompok P3A independen $>0,05$ yang berarti tidak terjadi gejala heteroskedasitas.

\section{Uji Multikolinearitas}

Uji multikolinearitas bertujuan untuk mengetahui apakah terjadi hubungan antar variabel independen dengan variabel independen lainnya. Model regresi yang baik seharusnya tidak terjadi hubungan antar variabel independennya. Apabila terjadi hubungan, maka terjadi masalah multikolinearitas. Gejala multikolinearitas dapat dilihat dengan nilai Variance Inflation Factor (VIF). Jika nilai Variance Inflation Factor (VIF) lebih kecil dari 10, maka tidak adanya gejala multikolinearitas pada model regresi dan sebaliknya.

Berdasarkan Uji Multikolinearitas, nilai Variance Inflation Factor (VIF) pada kelima faktor yang menjadi variabel independen pada model memiliki nilai kurang dari 10. Hal ini menunjukkan bahwa variabel-variabel independen dalam model regresi untuk tingkat partisipasi petani kelompok P3A desa Alatengae tidak memiliki hubungan linear satu sama lain

\section{Kesimpulan}

Berdasarkan tujuan penelitian serta hasil dan pembahasan pada penelitian ini, maka dapat ditarik beberapa kesimpulan sebagai berikut :

1. Tingkat Partisipasi Petani Anggota P3A dalam Kegiatan Pengelolaan Irigasi di tiap tahap pada P3A Mattirioalie (Hulu) dan P3A Sitiroang Deceng (Tengah) dalam kategori Sedang, yang berarti belum mampu mewujudkan kesadaran penuh akan pentingnya pengelolaan irigasi, sedangkan Tingkat Partisipasi pada P3A Saromase (Hilir) berada pada kategori yang tinggi.

2. Faktor-faktor yang mempengaruhi secara signifikan tingkat partisipasi petani responden kelompok P3A di Desa Alatengae yaitu faktor umur, Jumlah tanggungan, Pengalaman Berusahatani, Luas Lahan, Jarak Tempat Tinggal dari Saluran Irigasi, Jarak Sawah dari Saluran Irigasi. dan faktor-faktor yang tidak berpengaruh secara signifikan yaitu faktor Tingkat Pendidikan. 


\section{Daftar Pustaka}

[BPS] Badan Pusat Statistik. 2013. Maros Dalam Angka. Kerjasama BPS Kabupaten Maros dengan BDI Kabupaten Maros, Maros

Dajan, A. 1986. Pengantar Metode Statistik Jilid II. LP3ES. Jakarta.

Hadi, S. 1192, Metologi Research. Yogyakarta: Andi Offset, 1991.

Hasyim, H. 2003. Analisis Hubungan Faktor Sosial Ekonomi Petani Terhadap Program Penyuluhan Pertanian. Penelitian LP Universitas Sumatera Utara, Medan.

Indrawati, (2003). Partisipasi Masyarakat dalam Upaya Rehabilitasi Lahan dan Konservasi Tanah (RLKT), Jurnal Pengelolaan DAS Surakarta IX (1) 2003: 30-44.

Kolopaking, M. K Iman, dan Nawireja. 2001. “Pola Keikutsertaan Masyarakat Dalam Pengembangan Daerah Irigasi". Dalam : Sebuah Arahan Pengembangan. Mimbar Sosek, Jurusan Ilmu - ilmu Sosial Ekonomi Pertanian, Fakultas Pertanian, Institut Pertanian Bogor, Indonesia Volume 14 No. 2.

Mantra, I.B. 2004. Demografi Umum. Penerbit Pustaka Pelajar: Yogyakarta.

Notoadmojo, S. 2 010. Pendidikan Dan Perilaku Kesehatan. Jakarta: Buaya Ilmu Populer. Jakarta.

Rais, M. 2011. Studi Efisiensi Penggunaan Air Irigasi Terhadap Operasi dan Pemeliharaan Pada Lahan Persawahan di Daerah Irigasi Lamasi.Kiri. Skripsi.Universitas Andi Djemma. Palopo. Saptana, dkk. 2001. Rekayasa Optimalisasi Alokasi Air Irigasi dalam Rangka Peningkatan Produksi Pangan dan Pendapatan Petani. Buletin Agroekonomi. Pusat Penelitian dan Pengembangan Sosial Ekonomi Pertanian.

Sumaryanto, 2009. "Rekayasa Optimalisasi Alokasi Air Irigasi Dalam Rangka Peningkatan Produksi Pangan dan Pendapatan Petani". Dalam: Buletin Agro Ekonomi, Pusat Penelitian dan Pengembangan Sosial Ekonomi Pertanian. Makassar. Vol.1 No.3.

Yuni, A. 2017. “Tingkat Partisipasi Anggota P3A Dalam Program Pengembangan Jaringan Irigasi (PJI)". Dalam: Jurnal Jurusan Agribisinis, Universitas Lampung (JIIA, Vol 5 No. 3, Agustus 2017). 